
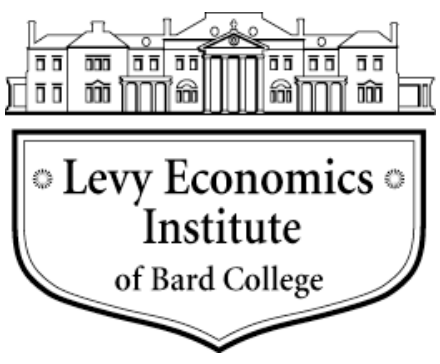

Working Paper No. 788

\title{
Modern Money Theory and Interrelations between the Treasury and the Central Bank: The Case of the United States
}

by

\section{Éric Tymoigne}

Levy Economics Institute of Bard College

March 2014

The Levy Economics Institute Working Paper Collection presents research in progress by Levy Institute scholars and conference participants. The purpose of the series is to disseminate ideas to and elicit comments from academics and professionals.

Levy Economics Institute of Bard College, founded in 1986, is a nonprofit, nonpartisan, independently funded research organization devoted to public service. Through scholarship and economic research it generates viable, effective public policy responses to important economic problems that profoundly affect the quality of life in the United States and abroad.

Levy Economics Institute

$$
\text { P.O. Box } 5000
$$

Annandale-on-Hudson, NY 12504-5000

http://www.levyinstitute.org

Copyright (C) Levy Economics Institute 2014 All rights reserved

ISSN 1547-366X 


\begin{abstract}
One of the main contributions of Modern Money Theory (MMT) has been to explain why monetarily sovereign governments have a very flexible policy space that is unconstrained by hard financial limits. Not only can they issue their own currency to pay public debt denominated in their own currency, but they can also easily bypass any self-imposed constraint on budgetary operations. Through a detailed analysis of the institutions and practices surrounding the fiscal and monetary operations of the treasury and central bank of the United States, the eurozone, and Australia, MMT has provided institutional and theoretical insights into the inner workings of economies with monetarily sovereign and nonsovereign governments. The paper shows that the previous theoretical conclusions of MMT can be illustrated by providing further evidence of the interconnectedness of the treasury and the central bank in the United States.
\end{abstract}

Keywords: Modern Money Theory; Monetary Policy; Fiscal Policy

JEL Classifications: E02, E42, E52, E62 


\section{INTRODUCTION}

One of the main contributions of Modern Money Theory (MMT) has been to explain why monetarily sovereign governments have a very flexible policy space that is unconstrained by hard financial limits. Not only can they issue their own currency to pay public debt denominated in their own currency, but also any self-imposed constraint on budgetary operations can be bypassed easily. Through a detailed analysis of the institutions and practices surrounding the fiscal and monetary operations of the Treasury and central bank of the U.S., the eurozone, and Australia, MMT has provided institutional and theoretical insights into the inner workings of economies with monetarily sovereign and non-sovereign governments. In terms of theory, MMT argues that taxes and bond offerings are not best conceptualized as funding sources for the Treasury, but rather as reserve draining devices to maintain price and interest-rate stability. As such they are necessary even if a government issues its currency to spend. This theoretical conclusion holds even if the Treasury may be required to tax and issue bond to fund itself. Another theoretical conclusion is that merging the central bank and the Treasury in a government sector can be done without a loss of generality for monetarily sovereign government. Separating the two adds complexity without adding insights (Mosler 1999; Bell 2000; Bell and Nell 2003; Bell and Wray 2003; Wray 1998, 2003a, 2003b, 2003c, 2012; Fullwiler 2006, 2009, 2011, 2013; Mitchell and Mosler 2002; Mitchell and Muysken 2008).

This paper shows that the previous theoretical conclusions of MMT can be illustrated by providing further evidence of the interconnectedness of the Treasury and the central bank in the United States. The first part of the paper shows that the early monetary history of the United States provides a direct validation of MMT's theoretical insights. The early history of US monetary policy was a period free of self-imposed constraints; the rest of the paper shows how some of the constraints have been bypassed in order to promote financial stability. The second part of the paper analyzes the role of the Treasury in monetary policy. The third part of the paper focuses on the funding cost and mechanisms of the Treasury. 


\section{FISCAL OPERATIONS DURING THE MASSACHUSETTS BAY COLONIES: A TEXTBOOK APPLICATION OF MMT}

In the early years of the US monetary system, the fiscal and monetary operations of the government were much simpler. There was no central bank, no primary market, and no debt limit. When a colonial government decided to spend, it issued its own securities to the public with a promise to take them back when tax payments were due. The bills of credit:

were by their terms receivable at the treasury in payment of government dues. They were originally put forth in anticipation of taxes, and provision in the tax levy was made [...] for a tax which should furnish the means for the prompt retirement of the bills emitted. [...] A part only of these notes was destroyed on their return to the treasury. Those remaining in the treasurer's hands were made use of at a later date by the province as a currency [...] (Davis 1901, 10, 15, 18, 20)

Unconvertible bills were injected when the Treasury spent, and drained when taxes came due. While residents of the colonies were at first skeptical about the value of the bills for economic and political reasons, they rapidly were used as currency and circulated at par:

When the government first offered these bills to creditors in place of coin, they were received with distrust. [...] their circulating value was at first impaired from twenty to thirty per cent. [...] Many people being afraid that the government would in half a year be so overturned as to convert their bills of credit altogether into waste paper, [...]. When, however, the complete recognition of the bills was effected by the new government and it was realized that no effort was being made to circulate more of them than was required to meet the immediate necessities of the situation, and further, that no attempt was made to postpone the period when they should be called in, they were accepted with confidence by the entire community [...] [and] they continued to circulate at par. (Ibid.)

It is straightforward to conclude that the funding capacity of the government was unlimited and that taxes were not a funding mechanism. Tax liabilities were a means to create a demand for the currency, and taxes allowed the draining of bills out of the economy, and validated the expectations of the population about taxes; thereby making the population willing to accept the bills in payment for goods and services. 
The governments of the colonies came to appreciate the importance of setting clear expectations regarding future tax collections and in implementing collections. However, they also noted that taxes tended to drain too many bills out of the economic system compared to what was desired by private economic units. This created a dilemma:

The retirement of a large proportion of the circulating medium through annual taxation, regularly produced a stringency from which the legislature sought relief through postponement of the retirements. If the bills were not called in according to the terms of the acts of issue, public faith in them would lessen, if called in there would be a disturbance of the currency. On these points there was a permanent disagreement between the governor and the representatives. (Ibid. 21)

Some knowledge of national accounting helps to solve this dilemma because, as long as the private sector desires to have a net accumulation of bills, there is no need to retire all of them through taxation in order to maintain their value; a government deficit is an equilibrium position (Godley and Lavoie 2007). Private economic agents desired to hold bills for other purposes than the payment of tax liabilities, namely daily expenses, private debt settlements, and precautionary savings. All this is in line with MMT's theoretical conclusion that the equilibrium fiscal position is ultimately determined by the desired net financial accumulation of the non-government sector, and that government can run a deficit because its currency is desired for purposes other than taxation (Wray 2012).

Today, the US Treasury's fiscal operations and Federal Reserve's monetary operations are constrained in multiple ways. One of the points of MMT is to show that these constraints are self-imposed and do not change the core purpose of taxes and bond offerings; moreover, the Treasury and Federal Reserve can, and do, easily bypass these constraints. MMT concludes that the case of the Massachusetts colonies is complex enough to understand the fiscal and monetary operations of contemporary economies within a monetarily sovereign government.

\section{MONETARY POLICY: THE ROLE OF THE TREASURY}

\subsection{Fiscal Balance and Interest Rate Stability}

A fiscal deficit lowers the federal funds rate (FFR), which tends to lower other interest rates, all else equal. While this was quite controversial when first noted by MMT proponents, it is now becoming more accepted (Lavoie 2013). This ought to be the case because this conclusion is not 
theoretical but rather factual. It comes from the balance sheet accounting of the Federal Reserve (Figure 1).

\section{Figure 1. Simplified Balance Sheet of the Federal Reserve}

\begin{tabular}{|l|l|}
\hline \multicolumn{1}{|c|}{ Assets } & \multicolumn{1}{c|}{ Liabilities and Net Worth } \\
\hline $\mathrm{A}_{1}$ : U.S. treasuries & $\mathrm{L}_{1}:$ Liabilities held by banks and the \\
$\mathrm{A}_{2}$ : Other assets & rest of the domestic private sector \\
& $\mathrm{L}_{2}:$ Liabilities held by the Treasury \\
& $\mathrm{L}_{3}:$ Liabilities held by others and net \\
& worth \\
\hline
\end{tabular}

$\mathrm{L}_{1}$ is the approximate monetary base (Treasury currency held by the domestic private sector must be added), and $\mathrm{L}_{2}$ is the outstanding amount of Federal Reserve notes and the Federal Reserve accounts held by the Treasury. Given that a balance sheet must balance, we know that:

$\mathrm{L}_{1} \equiv \mathrm{A}_{1}+\mathrm{A}_{2}-\mathrm{L}_{2}-\mathrm{L}_{3}$

To simplify, let us assume that all economic transactions involve electronic transfers of funds (no use of Federal Reserve or Treasury currency). As the Treasury spends in the domestic economy ( $\mathrm{L}_{2}$ goes down), the amount of reserves held by banks rises ( $\mathrm{L}_{1}$ goes up) as the Treasury credits the bank accounts of non-bank economic units. As the Treasury taxes $\left(\mathrm{L}_{2}\right)$ goes up, the amount of reserves held by banks declines ( $\mathrm{L}_{1}$ goes down). If the Treasury spends more than it taxes (i.e. runs a deficit), there is a net increase in $\mathrm{L}_{1}$ due to an increase in the amount of funds at the Federal Reserve accounts of banks. Surpluses lead to the exact opposite effect-they drain reserves out of the banking system and so reduce the monetary base.

Given that the demand for reserves by banks is highly inelastic, in normal times any ${ }^{1}$ excess reserves will tend to push down the FFR toward zero and any shortage of reserves will drive up the FFR rapidly. Thus, the Federal Reserve will need to offset the Treasury's fiscal operations unless it targets an FFR of 0 percent or gives up FFR targeting. Both the Treasury and the central bank are involved in these reserve management operations to maintain interest rate stability.

\footnotetext{
${ }^{1}$ This is a simplification. In a stable economic condition, banks may want to hold a small amount of excess reserves to avoid overdraft in interbank settlements and to meet customer withdrawals (Marquis 2002).
} 
If one focuses on a deficit, the central bank drains excess reserves by moving $A_{1}$ in the opposite direction of $\mathrm{L}_{2}$, the traditional open market operations (OMOs). OMOs involve selling treasuries to banks so that $\mathrm{A}_{1}$ declines and excess reserves are drained ( $\mathrm{L}_{1}$ declines). However, the central bank has a limited amount of treasuries that it can use for OMOs, so the Treasury must supply an adequate amount of treasuries for FFR targeting to be effective.

More broadly, a growing economy requires a growing monetary base, and therefore a growing amount of assets held by the Federal Reserve given the FFR target, which usually means that the amount of treasuries held by the Federal Reserve must rise. If there is a fiscal surplus, the outstanding amount of treasuries shrinks, which is a problem for a central bank that performs OMOs with that instrument. In addition, if the Federal Reserve acquires a too-high proportion of treasuries, it will disturb the liquidity of the treasury markets and thus the foundation of the financial markets. The Federal Reserve explicitly wants to avoid such an outcome and thus uses a cap in terms of the proportion of treasuries that it can hold (35 percent for T-bills, 15 percent for T-bonds) (Marshall 2002).

The growing fiscal surpluses of the late 1990s created a problem for the Federal Reserve. Members of the Federal Open Market Committee (FOMC) started to discuss what alternative securities the Federal Reserve could buy if surpluses continued as predicted by the Government Accountability Office (GAO). Leaving the US for a moment, the Australian Treasury was in the same situation in the early 2000s and came to the conclusion that treasuries were crucial for a well-functioning financial industry. As a consequence, the Australian Treasury decided to continue issuing treasuries even though it was running surpluses (Commonwealth of Australia 2003). An alternative answer to this problem is for the central bank to issue its own interestearning liabilities.

Beyond the provision of an adequate supply of treasuries, the Treasury is also involved in FFR targeting through the use of the Treasury tax and loan accounts (TT\&Ls). TT\&Ls are accounts of the Treasury at private banks. These accounts were first set up in 1917 to receive proceeds of Liberty Bond offerings, and in 1948 they also began to receive tax collections. The Treasury does not spend out of these accounts. When it needs to spend, the Treasury transfers funds from its TT\&Ls to its Federal Reserve general account. The Treasury general account 
(TGA) is the main part of $\mathrm{L}_{2}$ and transfers of funds from the TT\&Ls into the TGA drain reserves ( $\mathrm{L}_{2}$ goes up, $\mathrm{L}_{1}$ goes down) (U.S. Treasury 1955; U.S. Senate 1958).

TT\&Ls were created explicitly for the purpose of smoothing the impact of Treasury fiscal operations on reserves. For example, when the Treasury receives tax payments, it does not immediately transfer them into its TGA but rather keeps the funds in its TT\&Ls. This is tremendously helpful for the Federal Reserve when estimating the reserve supply conditions in

the federal funds market, and therefore how many OMOs are needed. Bell (2000), U.S. Treasury (1955), MacLaury (1977), Meulendyke (1998) show that the daily coordination between the Treasury and the Federal Reserve is extensive.

\subsection{Treasury's Monetary Policy during the 2007-2008 Crisis}

In usual circumstances, OMOs and TT\&L transfers are enough to help stabilize the FFR at its target but these tools were insufficient during the recent financial crisis. In December 2007, the Federal Reserve started to provide reserves to banks with liquidity problems through the Discount Window and emergency lending facilities (including the Term Auction Facility, followed by many others). These banks then paid their creditors, which led to excess reserves in the federal funds market. At that time, the FFR target was 4.25 percent and the Federal Reserve removed any unwanted reserves induced by the emergency loans. The goal was to maintain an amount of non-borrowed reserves consistent with the FFR target while helping financial institutions in difficulty.

Over a period of six months, the Federal Reserve sold about 40 percent of its treasuries, and had about $\$ 480$ billion left in June 2008. The amount of treasuries available for OMOs was actually smaller because, in March 2008, the Federal Reserve started to lend some treasuries for a month through the Term Securities Lending Facility (TSLF). In June 2008, the unencumbered amount of treasuries available for OMOs was around $\$ 360$ billion. By July 2008, a period of relative calm set in and emergency borrowing at the Federal Reserve no longer grew. The Federal Reserve had been successful at maintaining the FFR around its target, which was down to 2 percent in July. It was, however, evident that the Federal Reserve would rapidly run out of treasuries if more emergency borrowing occurred with an FFR target significantly above zero. 
On September 15, 2008 Lehman Brothers failed and this triggered a panic. The Federal Reserve responded by providing reserves through its emergency credit lines. By October 2008, it had injected over $\$ 1$ trillion of reserves through these means, which was inconsistent with an FFR target of 2 percent. However, draining \$1 trillion of reserves would have required selling many more assets than the amount of unencumbered treasuries that amounted to about $\$ 250$ billion in October and that were potentially needed for the TSLF. Instead the Federal Reserve used two strategies. The first strategy was to progressively lower the FFR target to 1.5 percent in early October, 1 percent at the end of October, and 0 to 0.25 percent in mid-December 2008. However, before it reached that 0 percent FFR target, the Federal Reserve had to drain excess reserves, and this is where a second strategy was employed that involved the Treasury in two ways.

First, as shown in Figure 2, the Treasury transferred funds into its TGA, which grew from $\$ 5$ billion in 2007 to $\$ 35$ billion in 2008, and eventually $\$ 110$ billion in 2009. Most of the funds came from its TT\&Ls that went from $\$ 70$ billion in 2007 to $\$ 39$ billion in 2008 and $\$ 2$ billion in 2009. However, the drainage of $\$ 30$ billion of reserves in 2008 and another $\$ 80$ billion in 2009 was not big enough to offset the $\$ 1$ trillion injection of reserves (Figure 3). Given that the Federal Reserve was unwilling to sell its remaining unencumbered treasuries, it asked the Treasury to issue T-bills for that purpose:

Today [September 17, 2008], the Treasury Department announced the initiation of a temporary Supplementary Financing Program. The program will consist of a series of Treasury bill auctions, separate from Treasury's current borrowing program, with the proceeds from these auctions to be maintained in an account at the Federal Reserve Bank of New York. Funds in this account serve to drain reserves from the banking system, and will therefore offset the reserve impact of recent Federal Reserve lending and liquidity initiatives. (New York Federal Reserve Bank Website)

The Treasury issued the following statement:

The Treasury Department announced today the initiation of a temporary Supplementary Financing Program at the request of the Federal Reserve. (U.S. Treasury Website)

The outstanding amount of supplementary financial program (SFP) bills rose rapidly to $\$ 560$ billion at the end of October 2008 and stayed there for a month. All funds obtained were put into a Treasury Special Funding Account (TSFA) at the Federal Reserve. After November, the 
amount of SFP bills declined quite dramatically, which led to instability in short-term markets. The Federal Reserve asked for more assistance but the Treasury was reluctant to help because of a growing debt-ceiling debate in Washington, DC (Ramanathan 2010). Ultimately, the Treasury agreed to roll over \$200 billion worth of SFP bills, even though at the end of 2009 and beginning of 2010 their outstanding amount dropped to almost zero. After February 2011, the outstanding amount of SFP bills progressively declined and by August 2011 all SFP bills had matured.

Overall, the Treasury helped drain up to $\$ 610$ billion of reserves in October and November 2008 via the TT\&L transfers and the SFP bills. While Treasury operations were not enough to bring the FFR close to its target (the FFR was consistently 60 basis points or more below target (Figure 4)), they prevented a complete collapse of the FFR to zero. In theory, the SFP bill rate provided a floor to the FFR, as T-bills trade at a rate slightly below the FFR. But the FFR fell below the rate on SFP bills because not enough of them were supplied to financial institutions with excess reserves. With the introduction of interest payments on reserve accounts on October 9, 2008, SFP bills became theoretically redundant; however the Treasury kept issuing them for at least two reasons (Santoro 2012, 8). First, SFP bills removed a substantial amount of reserves and so helped to preserve interest stability. While the interest rate on reserves is supposed to provide a floor for the FFR, this only applies if all entities with Federal Reserve currency can get an interest-paying account at the Federal Reserve, which is not the case for government-sponsored enterprises and some international institutions (Kahn 2010). Second, offerings of SFP bills satisfied a demand by the financial industry for default-free credit instruments.

From what the preceding sections have shown, one can conclude that the Treasury has issued securities for other purposes than funding itself. One reason is to provide a means of payment for the country; another is to help the Federal Reserve in its interest-rate stabilization operations; a third one is to help financial institutions meet their capital requirements and to provide a foundation upon which all other securities are valued by providing a proxy for the risk-free rate. MMT argues that these reasons for issuing treasuries are much more relevant in a monetarily sovereign government, because they do not result from a self-imposed constraint. They respond to a genuine need of the economic system unless an interest rate is paid on 
reserves (with rates varying with the maturity of the accounts, much like traditional demand and savings deposits), and there is wide access to central bank accounts for financial institutions.

Figure 2. Treasury Accounts, Yearly Average (Billions of Dollars)

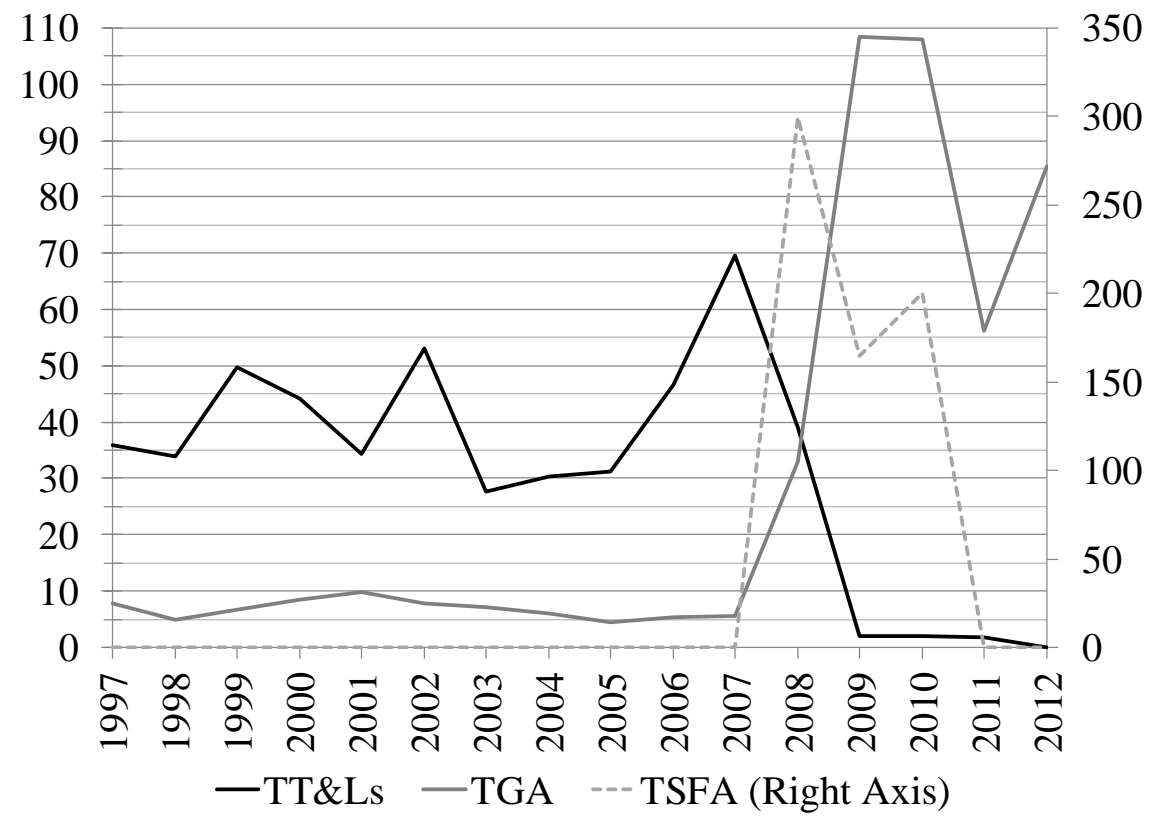

Source: Financial Management Service (United States Central Summary General Ledger Account Balances)

Figure 3. Federal Reserve Balance Sheet and Injection (+) and Drainage (-) of Reserves (Trillions of Dollars)

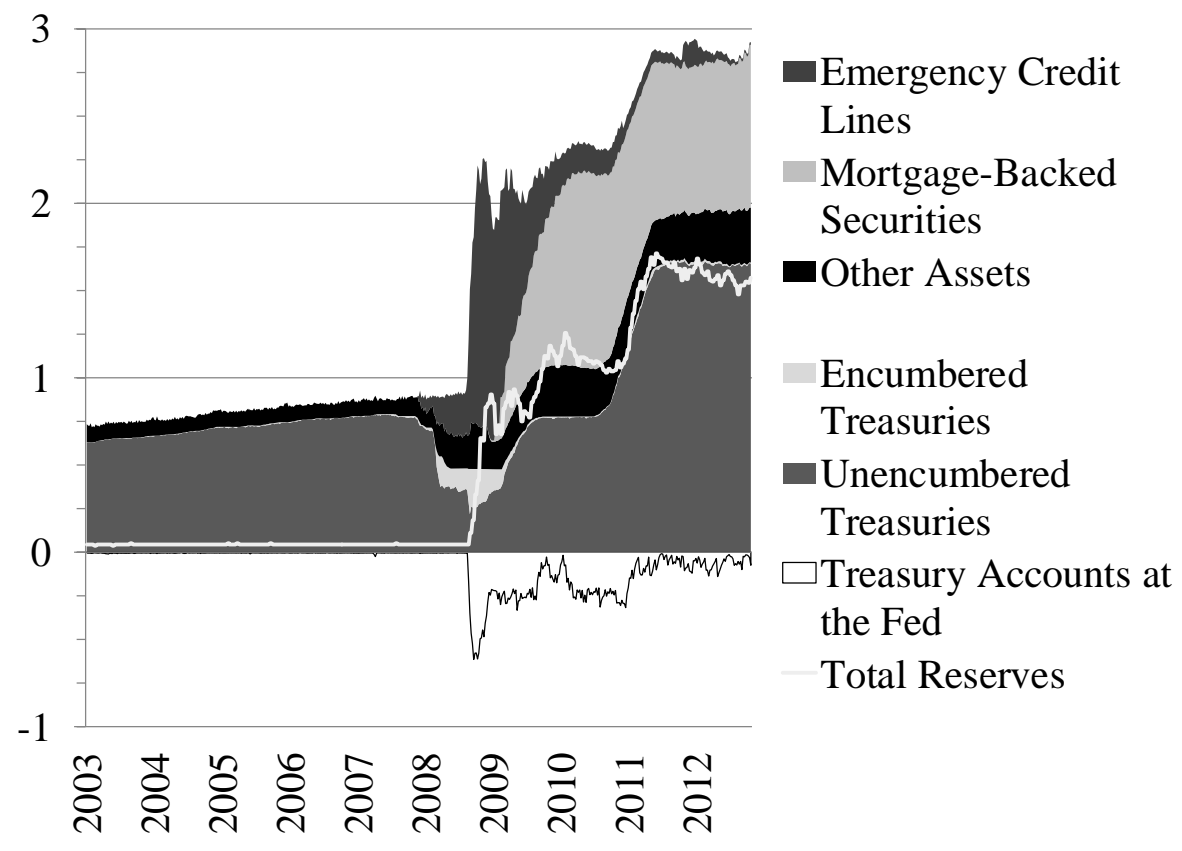

Source: Federal Reserve Board of Governors (H4.1, Table 1 and 1A) 
Note: Encumbered treasuries include treasuries lent overnight and through the TSLF.

Figure 4. Amount of Reserves drained by Treasury Operations, and Deviation from FFR target

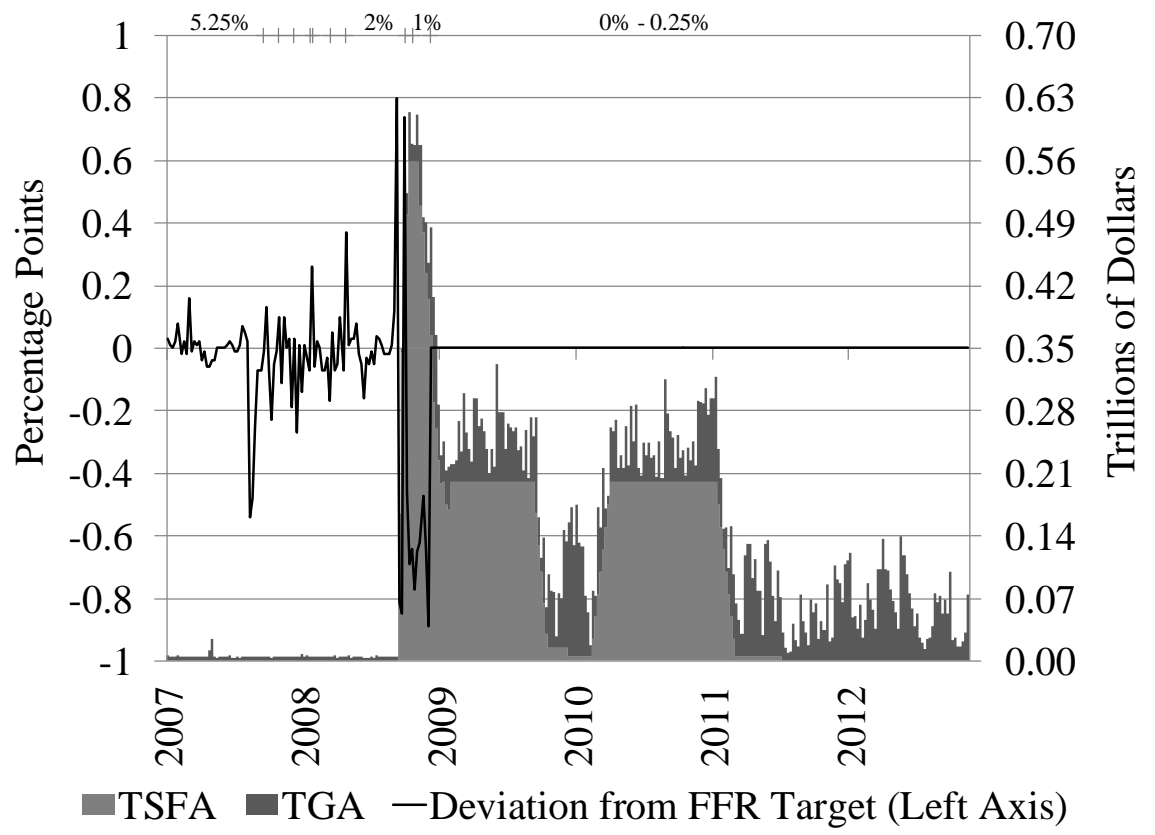

Sources: Federal Reserve Bank of New York, Federal Reserve Board of Governors

Note: Some FFR targets are shown at the top of the graph. Each separation represents a change in the target.

\section{FUNDING OF THE TREASURY}

One conclusion of MMT is that Treasury spending always involves monetary creation as private bank accounts are credited, while taxation involves monetary destruction as bank accounts are debited. The question becomes how the Treasury acquired the funds it has in its TGA; the answer is through taxation and bond offerings. While usually economists stop here, MMT goes one step further and wonders where the funds for taxation and bond purchases came from; the answer is from the Federal Reserve. This must be the case because, leaving aside TT\&Ls, taxes and bond offerings drain reserves, so the Federal Reserve had to provide the funds. The logical conclusion then, is that reserve injection has to come before taxes and bond offerings. More broadly, the theoretical insight that MMT draws is that government spending (by the Treasury or the central bank) must come first, i.e. it must come before taxes or bond offerings. Spending is done through monetary creation ex-nihilo in the same way a bank spends by crediting bank accounts; taxes and bond offerings lead to monetary destruction. 
As the following shows, in practice, injections of reserves related to the Treasury have come in several forms: monetary creation by the Treasury, funding of the Treasury by the central bank, funding of primary dealers by the central bank, and maturation of treasuries. The injection of reserves allows banks to buy treasuries or to complete tax payments.

\subsection{Funding Constraints and Means to Bypass Them}

Under the current budgetary procedures, the Treasury must issue securities to economic units other than the Federal Reserve to be able to fund a deficit (provided there are not enough funds in the TGA and TT\&Ls). The Treasury has at least four ways to bypass this budgetary procedure. The first one is to issue its own monetary instrument. The second way is to allow banks to buy treasuries by crediting TT\&Ls. The third way is to allow the Federal Reserve to provide a direct emergency or regular credit line to the Treasury. The fourth way is to have the Federal Reserve indirectly provide funding to the Treasury through banks. The Treasury uses, or has used, all these different techniques.

Regarding the first three methods to bypass the financial constraint, in the past the Treasury was responsible for a large quantity of the money supply and it printed United States notes until the 1960s. Of course, coins are still issued by the Treasury and it could stamp coins of any denomination. Beyond the issuance of monetary instruments, in the 1950s, the Treasury has also issued Tax Anticipation bills similar to the ones issued by the Massachusetts colonies. The bills were accepted at face value for payments of income and profit taxes on a specific date. In addition, the Treasury allowed banks to pay for the new bills by crediting the TT\&Ls. A central goal of allowing TT\&Ls crediting was to coordinate with the Federal Reserve in order to maintain interest-rate stability, by preventing drainage of reserves from the sale of treasuries:

The Treasury, on several occasions in the past, has permitted qualified depositary banks to make payment by a credit to the Treasury's account on their own books. The purpose of this provision was to facilitate the marketing of new offerings at times when member bank reserves were subjected to abnormal pressures. (Federal Reserve Bank of Richmond 1952, 7)

Monetary financing by the private banks occurred on a regular basis before 1929 through the War Loan Deposit Accounts (the former name of TT\&Ls) (Garbade 2008). This was not done at the discretion of banks. It was the Treasury telling banks if they could buy bills by crediting the 
bank account of the Treasury. The Treasury has not allowed banks do to this since October 1989 (U.S. Treasury 1989).

Beyond the issuance of monetary instruments and monetary financing by private banks, a third way for the Treasury to bypass its self-imposed financing constraints is through the direct involvement of the central bank. In the past, the Federal Reserve sometimes purchased treasuries directly from the Treasury either because an offering failed or because of a low TGA before tax receipts.

Prior to 1935 , there was no restriction on treasuries purchased by the Federal Reserve. It could buy treasuries directly from the Treasury and on the open market. The 1935 Banking Act amended Section 14 of the Federal Reserve Act to prohibit the Federal Reserve from purchasing treasuries directly from the Treasury. This was quite inconvenient for the Treasury because the:

Treasury has huge outpayments before tax receipts come in-we used to have securities maturating and interest due the 15th of March before the taxes came in - and in the meantime we had an overdraft, we were busted, and the Federal Reserve used to lend us money at those times (Burgess in U.S. Senate $(1957,897)$ )

In order to bypass the 1935 constraint the Treasury used the following financial trick:

Since under this law the Treasury could not borrow directly from the Federal [Reserve], we would sell to the commercial banks, participation in this overdraft. They would have lots of money, because we just had redeemed some securities and had not collected taxes (Ibid.)

By repaying some maturing securities, the Treasury provided the reserves needed by banks to purchase short-term certificates of indebtedness.

At the request of the Federal Reserve, which needed help to preserve stability in the money market, the 1942 Second War Powers Act removed the 1935 restriction subject to reapproval by Congress every two years (Board of Governors of the Federal Reserve 1942; U.S. House 1947; U.S Senate 1956). The Act allowed the outstanding amount of treasuries directly purchased by the Federal Reserve to be at most $\$ 5$ billion at any time. This funding source, which was not considered a central funding source by the Treasury, was mainly used as an emergency source in case the amount of funds in the TGA became too small:

The existence of the direct-purchase authority provides us with a margin of safety which permits us to let our cash balance fall to otherwise unacceptably low levels preceding 
periods of seasonally heavy revenues. [...] The direct-purchase authority is available to provide an immediate source of funds for temporary financing in the event of a natural emergency on a broader scale. While this has never happened, it is conceivable that financial markets could be disrupted at a time when large amounts of cash had to be raised to maintain governmental functions and meet the emergency. (Altman in U.S. House $(1978,10))$

Chairman Martin provides the Federal Reserve's perspective on this funding facility for the Treasury:

The use of this authority by the Federal Reserve enables the Treasury to avoid creating unnecessary financial strains that would otherwise occur if it had to draw heavily on its accounts especially during periods immediately preceding tax payment dates. Temporary Treasury borrowing at such times, followed by prompt repayment from the proceeds of tax payments, provides a smooth operating mechanism, without the abrupt money market fluctuations that would otherwise occur. (Martin in U.S. House $(1962,12)$ )

One may note again that a central purpose of this funding channel was to protect the federal funds market from adverse impacts associated with the need to replenish the TGA.

Figure 5 shows that the Treasury used this funding channel relatively rarely and usually for less than a week at a time. While $\$ 5$ billion was the maximum limit set by Congress, the Board of Governors had the discretion to set that limit lower. In practice, the maximum amount of "special short-term Treasury certificates" that the Federal Reserve was willing to buy varied between $\$ 500$ million and $\$ 5$ billion. The limit was usually set around $\$ 1$ or $\$ 2$ billion, but the Federal Reserve did increase the limit temporarily if needed by the Treasury. A June 8, 1979 Act (Public Law 96-18) allowed this power of Federal Reserve Bank to lapse after 1981, but the Board kept that power until the end of 1983 (Board of Governors of the Federal Reserve 1983). 
Figure 5. Maximum amount of Special Short-Term Treasury Certificates Purchased Directly from the U.S. Treasury, Maximum Maturity (Days, Shown above Bar), and Maximum Amount Outstanding Allowed by the Board.

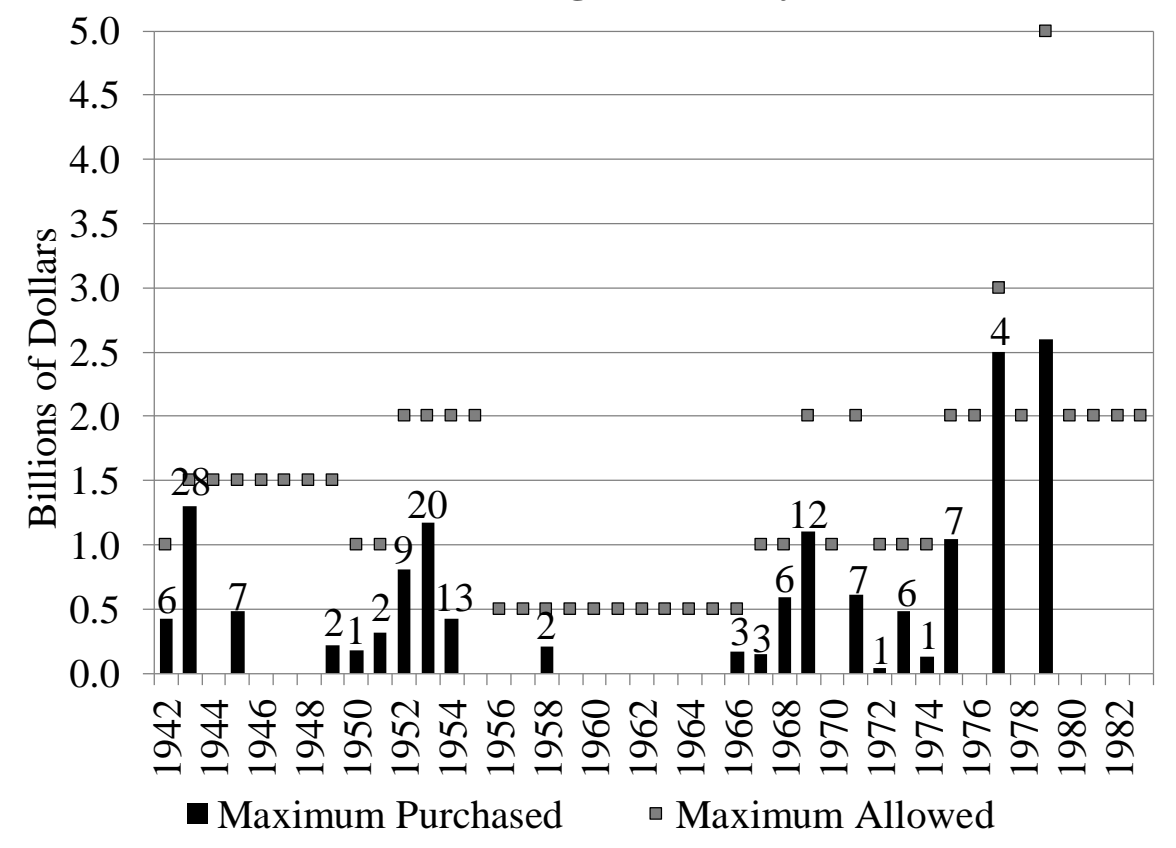

Source: U.S. Treasury $(1978,290)$, Annual Reports of the Board of Governors of the Federal Reserve System. Note: Maximum maturity is not available for 1979

However, the end of this direct purchase program was not a problem because, since the 1980s, this funding procedure became unnecessary as the Treasury coordinated with the Federal Reserve to keep around $\$ 5$ billion in its TGA at any given time, and as treasuries auctions became more successful. The Treasury took quite a long time to figure out how to properly offer its securities on the primary market. Well into the 1960s, the Federal Reserve would help by buying some bonds and notes in the primary market. A major reason why offerings were not successful had to do with the technique of issuance of bonds and notes for which auctioning was not well-established until the 1970s. T-bills were never really a problem as they immediately started to be issued at auction successfully (Garbade 2004, 2008; Hallowell and Williamson 1961).

Today, the most common way for the government to bypass the financing constraints is through a fourth artifact. Even though the Federal Reserve is not allowed to increase its holding of treasuries by participating in the primary treasuries market, it is indirectly involved in Treasury funding through three channels. First, it finances the primary dealers that participate in 
the treasuries auctions, and it does so by accepting treasuries as collateral for repos or by buying treasuries outright. The Federal Reserve is a major holder of treasuries with usually over 10 percent of outstanding public debt held by the public in the portfolio of the Federal Reserve (Figure 6). For example, the US special dealer banks always stand ready to purchase treasuries and the Federal Reserve ensures there are sufficient reserves to do so by supplying them through temporary repos (a matched purchase of Treasury debt with a requirement that the seller must repurchase later). While the Federal Reserve is not in that case directly buying the new issue directly from the Treasury, it uses the open market purchase to buy an existing bond in order to provide reserves needed for a private bank to buy the new security. The end result is exactly the same as if the central bank had bought directly from the Treasury. Second, the Federal Reserve is actively involved in setting the entire yield curve of treasuries either by focusing on the short end of the curve and influencing expectation about future short-term rates, or by buying and selling long-term treasuries in the secondary market. Third, the Federal Reserve is still a major participant in the primary market because it buys new treasuries to replace its maturing treasuries, which helps to ensure that refinancing of the Treasury goes smoothly (Edwards 1997).

One can conclude from the previous points that there is nothing written in stone in terms of fiscal operations. If tomorrow nobody is willing to take treasuries, the Treasury, with or without the help of the Federal Reserve, has the means to bypass that problem if it chooses to use them; it becomes a political issue rather than an economic one. The theoretical implication that MMT draws from this is that one can simplify the economic analysis without a loss of generality by assuming that the Federal Reserve directly funds the Treasury. 


\section{Figure 6. Federal Reserve Portion of the Public Debt held by the Public (Percent)}

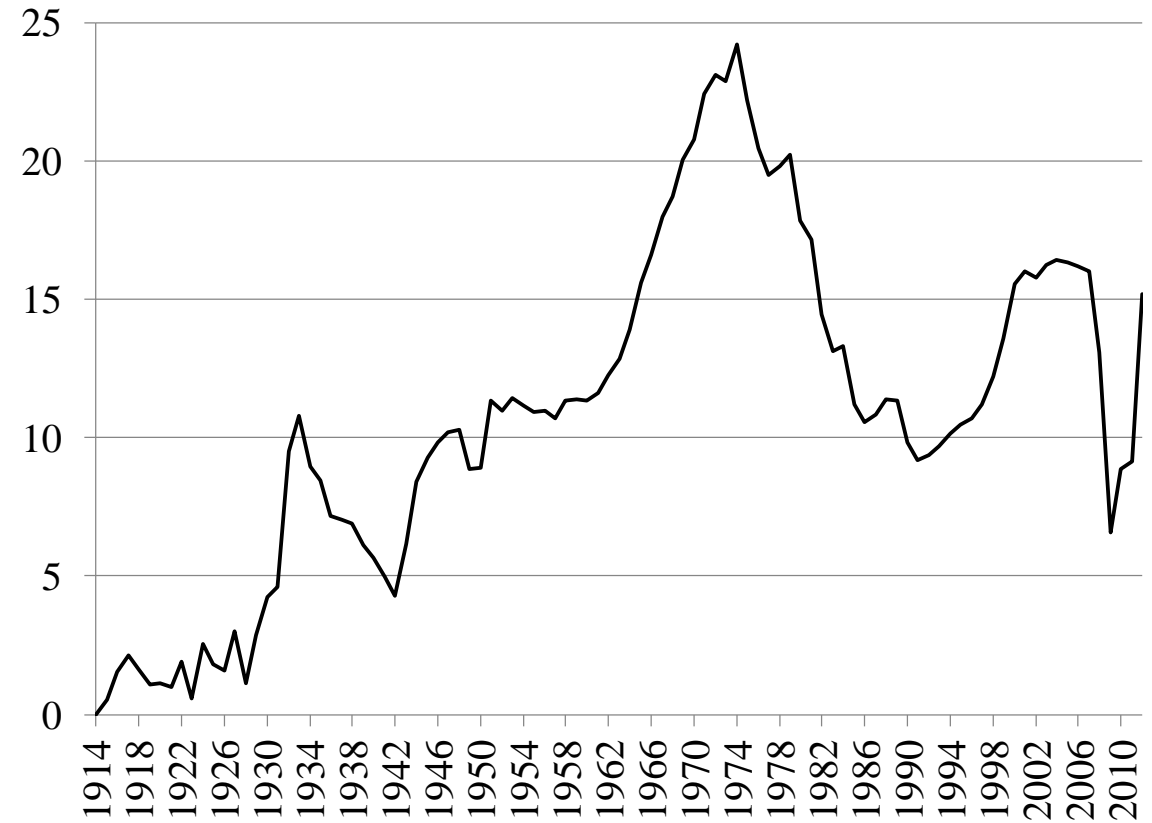

Source: Financial Management Service, Marshall (2002), http://www.usgovernmentdebt.us/

\subsection{Cost of Public Debt}

In a monetarily sovereign government, the government is able to have perfect control over the interest rate it pays on its debt. The government may choose not to use that power but it is a selfimposed constraint; it is a political decision — not an economic constraint. In practice, monetarily sovereign governments choose to go halfway; not totally controlling but also not letting interest rates go out of control. This semi-control comes in three ways. One is through the bidding process in the primary market for treasuries, another is through interest-ratemanagement strategies described in Section 2.2, and a third method is through debt management.

In a treasuries auction, two types of bidding are possible: competitive and noncompetitive bidding. Non-competitive bids means that participants in the primary market for treasuries accept whatever discount rate is determined at the auction. This type of bidding was introduced in 1947 to widen the market for bills among small bidders. For competitive bids, the government set up the auction to get the highest possible price for its securities.

Since November 1998, all Treasury securities have been auctioned according to the uniform-price method. [...] Previously, most securities had been issued according to the 
multiple-price method, meaning that securities were awarded at prices corresponding to the yield of each successful competitive bid. In such auctions, bidders must be concerned with the "winner's curse" - the tendency for a successful bidder to pay a price higher than the value assessed by other auction participants. By mitigating the winner's curse, the uniform-price auction may elicit more aggressive bids, possibly increasing the Treasury's revenue. (Dupont and Sack 1999, 788)

As noted earlier, it actually took quite a few decades for the Treasury to figure out the best offering mechanism as oversubscriptions or auction failures were quite common until the 1970s. Yield-auction instead of price-auction further improved the success of auctions, as did singleprice auctions.

Beyond the auction mechanisms of treasuries, the interest-rate policy of the Federal Reserve plays a crucial role in determining the level and slope of the yield curve on treasuries through its current and expected FFR. Correlation between FFR and T-bills is almost perfect and correlation between FFR and T-bond rates is very high. The Federal Reserve can also decide to set the entire yield curve. For nine years (1937-1945), the bankers' acceptance rate (the equivalent of the FFR at the time) was set at 7/16 of 1 percent ( 0.4375 percent); from 1942 to 1947 , the T-bills rate was set at $3 / 8$ of 1 percent $(0.375$ percent $)$, and T-bond rate was set almost perfectly at 2.5 percent from 1942 to 1945 (Figure 7). The recent Quantitative Easing policy is another example of similar yield curve targeting, albeit not as strong as during World War II.

Finally, the Treasury may improve its control over the cost of its debt by choosing the maturity it wants. If the Treasury wants to closely align its cost to the FFR, it may decide to issue only T-bills. In that case, the cost of the public debt will be under the control of the Federal Reserve. However, the Treasury usually also issues longer maturity securities, partly to fulfill the needs financial-market participants for long-term default-free liquid assets, and partly to avoid frequent refinancing at a higher interest rate if the FFR target goes up. The point is that if cost is the strict consideration, it is easy for the Treasury to be less subject to these costs by shortening the maturity of its outstanding debt. 
Figure 7. U.S. Interest rates in the 1930s, 1940s and 1950s.

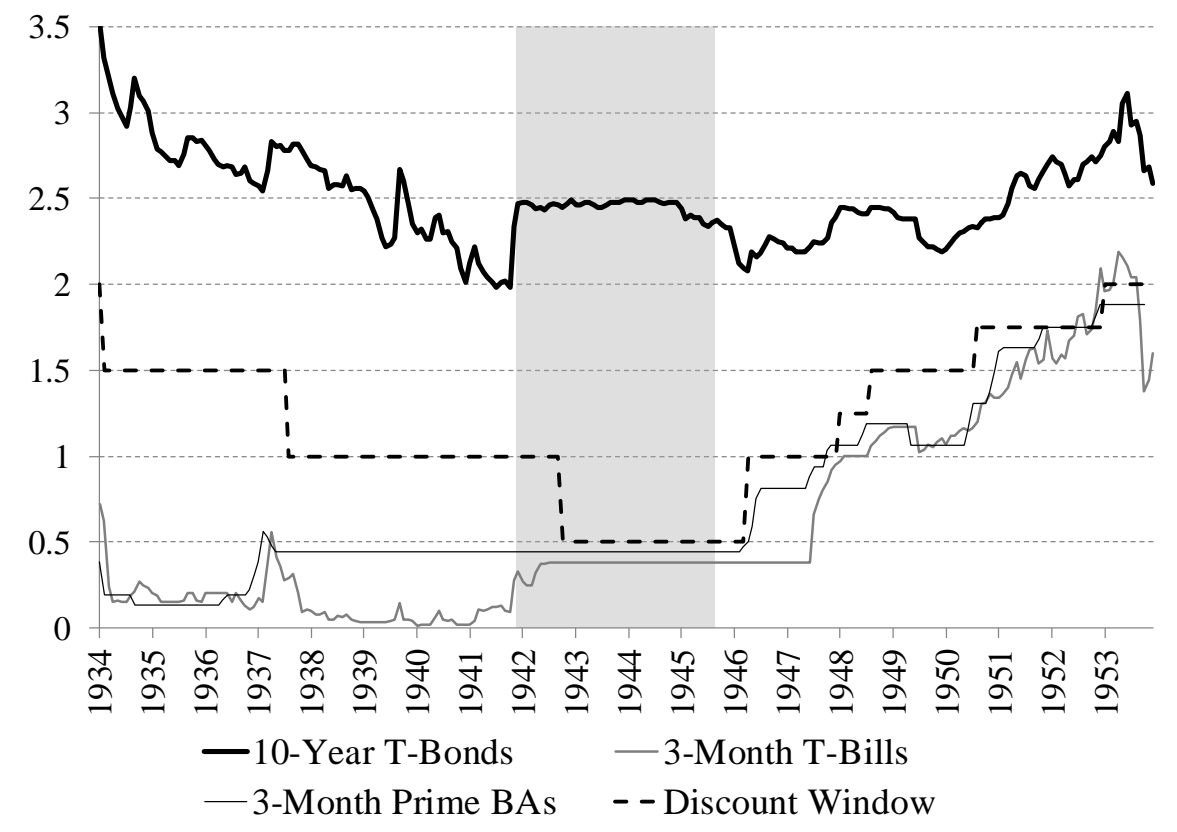

Source: NBER, Board of Governors of the Federal Reserve System Note: Grey area is represents U.S. involvement in World War Two.

\subsection{Public Debt and Debt Limit}

Beyond the prohibition of direct financing by the central bank, another major self-imposed constraint on the budgetary operations of the Treasury is that the U.S. Congress must approve the issuance of additional treasuries if the outstanding amount of treasuries reaches a specific value: the "debt ceiling." Given that Congress usually approves a budget that is in deficit, it must also periodically vote to raise the debt ceiling, but these two votes are done separately. As the current situation in the U.S. shows, if there is no agreement to raise the debt limit, a deficitspending budget cannot be implemented because the Treasury is not allowed to issue more securities to obtain the funds needed to close its budget.

The public debt is the outstanding amount of U.S. Treasury securities (USTS). It includes both marketable securities (mostly bills, notes, bonds and TIPS) and non-marketable securities (United States notes, Gold certificates, U.S. savings bonds, Treasury demand deposits issued to States and Local Governments, and others). The public debt held by the public is the 
outstanding amount of USTS held by entities outside the U.S. government. These entities include the Federal Reserve System, U.S. states and municipalities, foreign governments, and the private sector.

If one looks more closely at how the public debt is measured, one can quickly note the arbitrary nature of this measure, and that the debt limit can be bypassed easily. For example, coins are not counted as part of the public debt because:

In this context it is critical to realize that the stock of reserves, or money, newly issued by the government is not a debt of the government. The reason is that fiat money is not redeemable, in that holders of money cannot claim repayment in something other than money. Money is therefore properly treated as government equity rather than government debt, which is exactly how treasury coin is currently treated under U.S. accounting conventions (Benes and Kumhof 2012,6).

Unfortunately, this argument does not stand the ground of observation. The public debt does include a monetary instrument that has always been unconvertible - United States note — and two that were previously convertible but are no longer so: silver and gold certificates. The main difference between them and a Federal Reserve note is the color of the ink. Coins are similar to a United States note; both are unconvertible monetary instruments issued by the Treasury, one in paper form one in metal form.

One may note that the accounting treatment of coins as equity and the exclusion of Federal Reserve notes from the definition of public debt leads to a straightforward solution to reduce the public debt: convert all outstanding red (U.S. notes), blue (silver certificates), and yellow (gold certificates) currency into metal currency or green currency (Federal Reserve notes). Currently, that would eliminate $\$ 422$ million of public debt. However, this would not address the debt ceiling constraint because these components of the public debt are not subject to the debt limit, which leads us to another conclusion. In order to bypass the debt ceiling problem, the Treasury just needs issue zero-interest instantaneous maturity securities (U.S. notes, coins) instead of interest-paying securities or zero-coupon securities with a maturity higher than U.S. notes. If physical currency is too cumbersome as a means to perform transactions, the Treasury can issue coins (or notes) of any denomination (like a trillion-dollar platinum coin) and transfer them to the Federal Reserve against credit at its TGA. Or the President can use Section 4 of the $14^{\text {th }}$ Amendment. Surely, there are other means to bypass this 
constraint as long as the political will exists. The Treasury has used other accounting techniques to avoid default (Meulendyke 1998, 232, n.15).

\section{CONCLUSION}

MMT has provided a theoretical framework to think about how monetarily sovereign governments operate and their impacts on the economy. It shows that it is relevant for theoretical purpose to aggregate the central bank and the treasury into a government sector that finances itself through monetary creation. Taxes and bond offerings are central to maintaining the stability of the economic system, but they are not central to the funding of a monetarily sovereign government.

While some critics of MMT have made claims that the consolidation hypothesis lacks descriptiveness because it gets rid of important institutional constraints, one can argue that if it is descriptiveness that one wants one should include all institutional aspects. This means including institutional aspects that allow the Treasury and Federal Reserve/government to bypass the existing self-imposed constraints. This paper has provided some evidence that the self-imposed constraints on the Treasury and Federal Reserve are quite loose, and have been bypassed easily when too constraining or when the stability of the economy was a primary concern. In addition, they do not change the causalities at play, nor the impact on economic variables (impact on interest rates, exchange rates, balance sheets and national income), and so they are not relevant economic issues even though they may be politically relevant. Finally, the financial operations of the Treasury and the central bank are so intertwined that both of them are constantly in contact in order to make fiscal and monetary policy run smoothly. The Treasury gets involved in monetary policy and the central bank gets involved in fiscal policy. As such, the independence of the central bank is rather limited and it must ultimately support the Treasury in one way or another. MacLaury from the Federal Reserve Bank of Minneapolis summarizes all these points quite nicely:

The central bank is in constant contact with the Treasury Department which, among other things, is responsible for the management of the public debt and its various cash accounts. Prior to the existence of the Federal Reserve System, the Treasury actually carried out many monetary functions. And even since, the Treasury has often been 
deeply involved in monetary functions, especially during the earlier years. [...] Following the 1951 accord between the Treasury and the Federal Reserve System, the central bank was no longer required to support the securities market at any particular level. In effect, the accord established that the central bank would act independently and exercise its own judgment as to the most appropriate monetary policy. But it would also work closely with the Treasury and would be fully informed of and sympathetic to the Treasury's needs in managing and financing the public debt. [...] The Treasury and the central bank also work closely in the Treasury's management of its substantial cash payments and withdrawals of Treasury Tax and Loan account balances deposited in commercial banks, since these cash flows affect bank reserves. (MacLaury 1977)

The central bank and the Treasury must work together to support the monetary and financial systems because they are ultimately two sides of the same coin - the government sector.

This framework of thinking is important because it changes the nature of some economic debates. For example, most of the debates surrounding social security and Medicare are framed in terms of insolvency. Once one accepts that solvency is not an issue-government can always pay —one can reframe the debate in another way (Eisner 1998; Wray 2006). There is a problem with social security; it is a demographic problem, and not a financial problem. Payments can be made at the time they are due just by crediting bank accounts in a matter of seconds, but the goods and services that are needed may not be available. 


\section{REFERENCES}

Bell, S.A. (2000) "Do Taxes and Bonds Finance Government Spending?” Journal of Economic Issues, 34 (3): 603-620.

Bell, S.A. and Nell, E.J. (2003) The State, The Market, and The Euro. Northampton: Edward Elgar.

Bell, S.A. and Wray, L.R. (2002) "Fiscal Effects on Reserves and the Independence of the Fed", Journal of Post Keynesian Economics, 25 (2): 263-271.

Benes, J. and Kumhof, M. (2012) “The Chicago Plan Revisited,” International Monetary Fund Working Paper No. 12202.

Board of Governors of the Federal Reserve System (1942) $29^{\text {th }}$ Annual Report. Washington, DC: Board of Governors of the Federal Reserve System.

. (1983) $70^{\text {th }}$ Annual Report. Washington, DC: Board of Governors of the Federal Reserve System.

Commonwealth of Australia (2003) Budget Strategy and Outlook 2003-04, 2003-04 Budget Paper No. 1. Canberra: Commonwealth of Australia.

Davis, A. (1901) Currency and Banking in the Province of the Massachusetts-Bay, Part 1. New York: Macmillan.

Dupont, D. and Sack, B. (1999) "The Treasury Securities Market: Overview and Recent Developments." Federal Reserve Bulletin, December: 785-806.

Edwards, C.L. (1997) “Open Market Operations in the 1990s,” Federal Reserve Bulletin, November: 859-874.

Eisner, R. (1998) "Save Social Security from its Saviors," Journal of Post Keynesian Economics, 21 (1): 77-92.

Federal Reserve Bank of Richmond (1952) "Tax Anticipation Bills---A Buy for Bankers." Federal Reserve Bank of Richmond Monthly Review, December: 7-8.

Fullwiler, S.T. (2006) "Setting Interest Rates in the Modern Money Era," Journal of Post Keynesian Economics, 28 (3): 495-525.

. (2009) "The Social Fabric Matrix Approach to Central Bank Operations: An Application to the Federal Reserve and the Recent Financial Crisis." In Natarajan, Tara, Wolfram Elsner, and Scott Fullwiler, (eds.) Institutional Analysis and Praxis: The Social Fabric Matrix Approach, 123-169. New York, NY: Springer. 
. (2011) “Treasury Debt Operations: An Analysis Integrating Social Fabric Matrix and Social Accounting Matrix Methodologies.” Mimeograph.

. (2013) "Modern Central Bank Operations: The General Principles.” In Basil Moore and Louis-Philippe Rochon (eds.), Post-Keynesian Monetary Theory and Policy:

Horizontalism and Structuralism Revisited, Cheltenham: Edward Elgar.

Garbade, K.D. (2004) “The Institutionalization of Treasury Note and Bond Auctions, 1970-75," Federal Reserve Bank of New York Economic Policy Review, May: 29-45.

. (2008) "Why the U.S. Treasury Began Auctioning Treasury Bills in 1929." Federal Reserve Bank of New York Economic Policy Review, July: 31-47

Godley, W. and Lavoie, M. (2007) Monetary Economics: An Integrated Approach to Credit, Money, Income, Production and Wealth, New York: Palgrave Macmillan.

Hallowell, B.C. and Williamson, K.M. (1961) "Debt Management's Contribution to Monetary Policy," Review of Economics and Statistics, 43 (1): 81-84.

Kahn, G.A. (2010) “Monetary Policy under a Corridor Operating Framework," Federal Reserve Bank of Kansas City Economic Review, Fourth Quarter: 5-34.

Lavoie, M. (2013) "The Monetary and Fiscal Nexus of Neo-Chartalism: A Friendly Critique," Journal of Economic Issues, 47 (1): 1-31.

Maclaury, B. (1977) "Perspectives on Federal Reserve Independence - A Changing Structure for Changing Times," in Federal Reserve Bank of Minneapolis (ed.) 1976 Annual Report. Minneapolis: Federal Reserve Bank of Minneapolis.

Marquis, M. (2002) “Setting the Interest Rate," Federal Reserve Bank of San Francisco Economics Newsletter, No. 2002-30.

Marshall, D. (2002) "Origins of the Use of Treasury Debt in Open Market Operations: Lessons for the Present," Federal Reserve Bank of Chicago Economic Perspective, First Quarter: 45-54.

Meulendyke, A.M. (1998) U.S. Monetary Policy and Financial Markets. New York: Federal Reserve Bank of New York.

Mitchell, W.F., and Muysken, J. (2008) Full Employment Abandoned: Shifting Sands and Policy Failures. Cheltenham: Edward Elgar

Mitchell, W.F., and Mosler, W. (2002) "Public Debt management and Australia's Macroeconomic Priorities" Center for Full Employment and Equity, Working Paper No. 02-13. 
Mosler, W. and Forstater, M. (1999) "A General Framework for the Analysis of Currencies and Commodities," in Davidson P. and J.A. Kregel (ed) Full Employment and Price Stability in a Global Economy, 166-177. Northampton: Edward Elgar Publishing, Inc, 1999.

Ramanathan, K. (2010) “Unwinding the Treasury Supplementary Financing Program,” Pyramis Investment Perspective.

Santoro, P.J. (2012) "The Evolution of Treasury Cash Management during the Financial Crisis," Federal Reserve of New York Current Issues in Economics and Finance, 18 (3): 1-8.

Standard and Poor's (2007) Sovereign Credit Ratings: A Primer. New York: Standard and Poor's.

U.S. House (1947) Direct Purchases of Government Securities by Federal Reserve Banks. Hearing before the Committee on Banking and Currency. $80^{\text {th }}$ Congress, $1^{\text {st }}$ Session. March 3, 4, and 5, 1947. Washington, D.C.: Government Printing Office.

(1962) Amendment of Section 14(b) of the Federal Reserve Act. Hearing before the Subcommittee No. 1 of the Committee on Banking and Finance. $87^{\text {th }}$ Congress, $2^{\text {nd }}$ Session. June 27, 28 1978. Washington, D.C.: Government Printing Office.

. (1978) Federal Reserve-Treasury Draw Authority. Hearings before the Subcommittee on Monetary Policy of the Committee on Banking, Finance and Urban Affairs, $95^{\text {th }}$ Congress $2^{\text {nd }}$ Session. June 27, 28 1978. Washington, D.C.: Government Printing Office.

U.S. Senate (1957) Investigation of the Financial Condition of the United States. Hearings before the Committee on Finance. $85^{\text {th }}$ Congress, $1^{\text {st }}$ Session. July 29, 30, 31, August 1 , 2, 3, 6, 7, 8, and 9, 1957. Washington, D.C.: Government Printing Office.

. (1958) Debt Ceiling Increase. Hearings before the Committee on Finance. $85^{\text {th }}$ Congress, $2^{\text {nd }}$ Session. January 27, 28, February 4 and 7, 1958. Washington, D.C.: Government Printing Office.

U.S. Treasury (1955) Annual Report of the Secretary of the Treasury on the State of the Finances for the Fiscal Year Ended June 30 1955. Washington, D.C.: Government Printing Office.

. (1978) Annual Report of the Secretary of the Treasury on the State of the Finances, Fiscal Year 1978. Washington, D.C.: Government Printing Office.

(1989) "Treasury Discontinues Use of TT\&L Accounts for Securities Payments," Treasury News, August 19. Washington, D.C.: Department of the Treasury.

Wray, L.R. (1998) Understanding Modern Money: The Key to Full Employment and Price Stability. Northampton, Mass.: Edward Elgar. 
. (2003a) "Functional finance and US government budget surpluses in the new millennium," in E. J. Nell and M. Forstater (eds) Reinventing Functional Finance: Transformational Growth and Full Employment, 141-159. Northampton: Edward Elgar. . (2003b) "Seigniorage or sovereignty?," in L.-P. Rochon and S. Rossi (eds) Modern Theories of Money, 84-102, Northampton: Edward Elgar.

. (2003c) "Is Euroland the next Argentina?" Center for Full Employment and Price Stability, Working Paper 23.

. (2006) "Social Security in an aging society," Review of Political Economy, 18 (3): 391412.

. (2012) Modern Money Theory: A Primer on Macroeconomics for Sovereign Monetary Systems. New York: Palgrave Macmillan. 